\title{
Seed dispersal by neotropical waterfowl depends on bird species and seasonality
}

\author{
Giliandro G. Silva ${ }^{1}$ (D) | Andy J. Green ${ }^{2}$ (D) | Pedro Hoffman ${ }^{1}$ (D) | Vinícius Weber ${ }^{1}$ (D) | \\ Cristina Stenert $^{1}$ (D) | Ádám Lovas-Kiss ${ }^{3}$ (D) | Leonardo Maltchik ${ }^{1}$ (D)
}

${ }^{1}$ Laboratory of Ecology and Conservation of Aquatic Ecosystems, Universidade do Vale do Rio dos Sinos - UNISINOS, São Leopoldo, Brazil

${ }^{2}$ Department of Wetland Ecology, Estación Biológica de Doñana (EBD-CSIC), Sevilla, Spain

${ }^{3}$ Wetland Ecology Research Group, Department of Tisza Research, MTA Centre for Ecological Research-DRI, Debrecen, Hungary

\section{Correspondence}

Giliandro G. Silva, Laboratory of Ecology and Conservation of Aquatic Ecosystems. Universidade do Vale do Rio dos Sinos - UNISINOS. 950 Unisinos Avenue. São Leopoldo, RS, Brazil.

Email: giliandrog@gmail.com

Funding information

Conselho Nacional de Desenvolvimento Científico e Tecnológico, Grant/Award Number: 52370695-2; Ministerio de

Economía y Competitividad

\section{Abstract}

1. Waterbird-mediated endozoochory is an essential mechanism for the dispersal of sessile organisms in freshwater ecosystems. However, in the neotropics there are no previous studies of how different waterbird species vary in the dispersal functions they perform, and how seasonality influences endozoochory. In this study, we identified plant diaspores dispersed in faeces of five South American waterfowl (Brazilian teal Amazonetta brasiliensis, yellow-billed teal Anas flavirostris, ringed teal Callonetta leucophrys, coscoroba swan Coscoroba coscoroba, and whitefaced whistling-duck Dendrocygna viduata).

2. We collected 165 faecal samples from five wetlands in southern Brazil surrounded by pasture and rice fields, then separated and measured intact seeds and other diaspores. Using generalised linear models, we tested how diaspore abundance and taxonomic richness differed among bird species and between cold (AprilSeptember) and warm (October-March) periods. We also analysed bird-specific and seasonal variations in diaspore composition through principal coordinates analysis and permutational multivariate analysis of variance. We used indicator species analysis to determine which diaspore species discriminated between bird species and seasons. Finally, we measured diaspore length in order to analyse differences among waterfowl species in the size of diaspores dispersed.

3. We found 2,066 intact diaspores from 40 different plant taxa, including seeds of 37 angiosperms and diaspores of Lycophyta (Isoetes cf. maxima), Pteridophyta (Azolla filiculoides), and Charophyceae. There was at least one diaspore in 65\% of all faecal samples. Diaspores of native amphibious and emergent plants were dominant. We found 1,835 diaspores (from 33 taxa) in the cold period but only 231 (23 taxa) in the warm period. Seeds of the grass Zizaniopsis bonariensis and of the sedge Rynchospora sp. were the most abundant taxa. A strong interaction between bird species and season was the most important predictor of variation in both taxonomic richness and abundance of diaspores. The taxonomic composition of diaspores differed among waterfowl species and season. Indicator species analysis identified 12 plant taxa associated with particular bird species and seasons. Coscoroba swan, the largest bodied species in our study dispersed a higher proportion ( $8.2 \%$ ) of large (length $>2 \mathrm{~mm}$ ) seeds. 
4. Despite considerable overlap, there are important differences in the plants dispersed by each species, and the smallest (ringed teal) and largest (coscoroba swan) birds are particularly different. All five waterfowl species are distributed over wide areas of South America and here we demonstrated that they are likely to be important plant vectors connecting wetland species at different geographical scales. Many of these plants have previously been assumed to lack mechanisms for longdistance dispersal.

\section{KEYWORDS}

diaspores, endozoochory, neotropics, waterbird, wetlands

\section{1 | INTRODUCTION}

Dispersal is a key ecological process underlying species distribution (Lomolino, Riddle, Whittaker, \& Brown, 2010). For organisms with little or no locomotion capacity, transport vectors are fundamental to the spread of propagules or mature individuals away from their places of birth or germination (Heleno \& Vargas, 2015; Tesson et al., 2015). Many plant species have animals as dispersal vectors, where whole plants or their diaspores are transported on feathers, hair, or skin (epizoochory), or more often inside the digestive tract (endozoochory) (Coughlan, Kelly, Davenport, \& Jansen, 2017; Green, Soons, Brochet, \& Kleyheeg, 2016). Interactions between vertebrates and plants with fleshy fruits based on endozoochory have been well studied, with many examples from the neotropics (Galetti, Keuroghlian, Hanada, \& Morato, 2001; Levey, Silva, \& Galetti, 2002; Wenny, Sekercioglu, Cordeiro, Rogers, \& Kelly, 2016). Recent studies have shown that endozoochory is also important for a range of aquatic and terrestrial plant species lacking a fleshy fruit, with herbivorous, granivorous, and omnivorous waterbirds acting as excellent vectors for long-distance dispersal (Green et al., 2016; Hattermann, Bernhardt-Römermann, Otte, \& Eckstein, 2019; Viana, Santamaria, \& Figuerola, 2016).

Waterbird-mediated zoochory allows wetland species to cross the terrestrial matrix between isolated waterbodies (Figuerola \& Green, 2002), providing a vital ecological function to freshwater communities (Green \& Elmberg, 2014). Waterbirds are highly mobile, widely distributed and abundant, making them good dispersal vectors at different spatial scales (Green et al., 2016; Kleyheeg et al., 2019). Amongst the waterbirds, waterfowl (Anatidae-duck, geese, and swans) are the best-known dispersers of plant diaspores (Green et al., 2016; Lovas-Kiss, Vizi, Vincze, Molnár, \& A., \& Green, A. J., 2018; Silva et al., 2018; Wilkinson, Lovas-Kiss, Callaghan, \& Green, 2017).

How dispersal ability varies among waterfowl species, and the underlying causes of these differences, remain poorly understood, although bird morphology, foraging behaviour, gut anatomy, and movement patterns are all thought to play important roles (Figuerola, Green, \& Santamaría, 2003; Green et al., 2016; Reynolds \& Cumming, 2016a, 2016b; van Leeuwen, Van der Velde, van Groenendael, \& Klaassen, 2012). Seasonality is expected to influence plant dispersal, partly since the phenological match between seed availability and the presence of waterfowl in the area may be crucial to dispersal rates (Clausen, Nolet, Fox, \& Klaassen, 2002), although studies from the Mediterranean region indicate that seed dispersal can occur at high rates for months after seeds are produced (Brochet, Guillemain, Fritz, Gauthier-Clerc, \& Green, 2010; Figuerola et al., 2003).

Since the seminal work by V.W. Proctor and colleagues in the USA (e.g. de Vlaming \& Proctor, 1968), studies on endozoochory by waterfowl have predominantly been conducted in Europe (reviewed by Green et al., 2016), but in recent years there have been important studies in Africa (Reynolds \& Cumming, 2016a, 2016b), Oceania (Bartel, Sheppard, Lovas-Kiss, \& Green, 2018), and North America (Costea et al., 2016; Farmer, Webb, Pierce, \& Bradley, 2017; Green, Frisch, Michot, Allain, \& Barrow, 2013). In South America, Summers and Grieve (1982) cited upland goose (Chloephaga picta) and ruddyheaded goose (Chloephaga rubidiceps) as potential seed dispersers of fleshy-fruit plants in the Falkland Islands. Additionally, Willson, Traveset, and Sabag (1997) observed seeds of four fleshy-fruit plants in faeces of upland goose and ashy-headed goose (Chloephaga poliocephala) in Tierra del Fuego. Russo, Robertson, MacKenzie, Goffinet, and Jimenez (2020) found evidence that these geese species also disperse mosses by endozoochory. Silva et al. (2018) found whole plantlets of watermeal (Wolffia columbiana) surviving in white-faced whistling-duck droppings.

Here, we identified plant diaspores dispersed in faeces of five syntopic South American Anatidae: three Anatinae (Brazilian teal, ringed teal, and yellow-billed teal), an Anserinae (coscoroba swan), and a Dendrocygninae (white-faced whistling-duck). We tested how the abundance, species richness, and species composition of plant diaspores dispersed by endozoochory changed among bird species and seasonality. We expected important variation between bird species, reflecting known differences in their morphology and foraging ecology, including their body size (Kear, 2005a, 2005b). We also expected changes between the warm and cold periods of the year, reflecting differences in the production and availability of diaspores of different plants, and likely seasonal changes in diet (e.g. greater focus on invertebrates during the nesting period, Kear, 2005a, 2005b). 


\section{2 | METHODS}

\section{1 | Sampling procedures}

Faecal samples were collected in Santa Vitória do Palmar, in the Coastal Plain of southern Brazil (Figure S1), a region composed of a mosaic of permanent and temporary wetlands mixed with native grassland, livestock grazing, commercial forests, and ricefields. All five wetlands sampled were surrounded (within less than $50 \mathrm{~m}$ ) by ricefields and livestock farms. The percentage of each land use (rice or livestock) changes annually according to the rice cycle and actions taken by landowners to expand pastures. During the warm period, the water surface area is reduced, leading the study wetlands to be totally isolated from ricefields. During the cold period, higher water levels lead to hydrological connectivity between the study wetlands and rice fields. The estimated flooded area of each wetland varied between 0 and 0.04 ha during the warm period, and between 0.3 and 3.9 ha during the cold period. The wetlands of this region are important to resident waterbird species as well as austral and boreal migrants that winter or breed in the region (Belton, 1994; Guadagnin \& Maltchik, 2007; Guadagnin, Maltchik, \& Fonseca, 2009; Guadagnin, Peter, Rolon, Stenert, \& Maltchik, 2012; Maltchik, Rolon, Stenert, Machado, \& Rocha, 2011; Sick, 1997). Average temperatures ranges from $16^{\circ} \mathrm{C} \pm 2$ to $26^{\circ} \mathrm{C} \pm 3$ (S.E.) in the warm period (OctoberMarch), and from $10^{\circ} \mathrm{C} \pm 2$ to $19^{\circ} \mathrm{C} \pm 2$ (S.E.) in the cold period (April-September; Rio Grande do Sul, 2019). Although precipitation is similar in both periods (warm: $117 \pm 15 \mathrm{~mm}$; cold: $123 \pm 8 \mathrm{~mm}$ ), differences in evapotranspiration rates (warm: $103 \pm 29 \mathrm{~mm}$; cold: $41 \pm 14 \mathrm{~mm}$ ) make the warm period drier.

We collected 165 droppings from five waterfowl species (Brazilian teal, $n=40$; coscoroba swan, $n=22$; ringed teal, $n=31$; white-faced whistling-duck, $n=40$; yellow-billed teal, $n=32$ ) in five wetlands located 1-9 km apart, during seven field trips lasting from 4 to 7 days each. Three trips were carried out between October 2017 and January 2018, in the warm period, and four in August 2017, April, May, and June 2018, during the cold period. We grouped samples collected during the austral autumn and winter as the cold period, and the austral spring and summer as the warm period. The warm period (spring and summer) is the main breeding season in the study region, except for Brazilian teal which reproduces year-round, and for occasional breeding of resident coscoroba swan during the cold period. All bird species studied can nest in the early warm period, and raise their offspring before the end of the warm period (Belton, 1994; Calabuig, Green, Menegheti, Muriel, \& PatiñoMartínez, 2010; Dias \& Fontana, 2002; Maurício et al., 2013). At the end of the warm period, many coscoroba swans migrate from this region to Argentina (Calabuig et al., 2010), and only a few pairs or family groups remain. The other species studied stay in the region year-round, forming flocks of tens or hundreds of individuals in the cold period, although ringed teal and white-faced whistling-duck were sometimes absent in the study wetlands.

The foraging behaviours of the waterfowl (assigned as dabbling, diving, grazing) were observed in the field over the sampling period (about $200 \mathrm{hr}$ of sampling effort in total). Coscoroba swan (easily the largest species) often fed in the deepest water (1-1.5 m) with head or neck partially submerged, usually apart from the other species, and also grazed alone around lake edges. Brazilian teal, white-faced whistling-duck, and yellow-billed teal fed in mixed flocks in the water column at depths of up to $0.5 \mathrm{~m}$, and ringed teal joined these species mainly when feeding at shallower depths. Brazilian teal, ringed teal, and yellow-billed teal mainly fed by dabbling at the water surface, and Brazilian teal were also observed up-ending (see Green, 1998). White-faced whistling-duck fed on vegetation by submerging their head in the water, or by grazing around lake edges. No species was seen diving.

We located monospecific groups resting or feeding around lake edges and collected fresh droppings from the grass, with a minimum distance of $1 \mathrm{~m}$ between samples to prevent resampling of the same individuals. We closely inspected all droppings to avoid contamination from the substrate, then stored them individually in plastic tubes. As our study area is up to $500 \mathrm{~km}$ from the laboratory, and each trip lasted from 4 to 10 days, we froze samples $\left(-4^{\circ} \mathrm{C}\right)$ to avoid fungal infestation. Therefore, we did not test the germinability of seeds. However, previous work has firmly established the quantification of intact seeds recovered from faeces as an adequate proxy for dispersal rate (Green et al., 2016; van Leeuwen et al., 2012).

The samples were weighed and washed in tap water using a sieve $(53 \mu \mathrm{m})$ in the laboratory at UNISINOS University. We used a Bogorov chamber in a stereomicroscope $(1.6 \times$ to $5 \times$ magnification) to separate the diaspores from the other materials. We initially grouped the diaspores by morphotypes, then used literature to identify them to the lowest possible taxonomic level (see References in Supporting Information). We only counted intact diaspores, discarding broken or empty ones.

\section{2 | Data analyses}

We analysed the effects of bird species, seasons and faecal weight on the richness and abundance of diaspores using generalised linear models. Model parameters were estimated by maximum likelihood (Laplace approximation). All models fitted best with a negative binomial error distribution, which showed less overdispersion than a Poisson error distribution. In the model of diaspores abundance, we excluded one outlier to improve the model fit, this being a yellowbilled teal sample with 489 seeds of Rynchospora sp. We tested for main effects and interactions. We compared these effects against null models (intercept only) and performed model selection using the Akaike information criterion (AIC) (Burnham \& Anderson, 2002), retaining only models with $\Delta \mathrm{AIC}<2.0$ for further inference. We fitted all the generalised linear models in the $\mathrm{R}$ statistical environment $\mathrm{v}$. 3.6.1 using the function gIm.nb of the package Ime4 (R Development Core Team, 2019).

To assess diaspores composition variation among bird species and seasons, we used principal coordinates analysis and permutational multivariate analysis of variance using the Bray-Curtis 
distance matrix and 9,999 permutations to validate the model significance of permutational multivariate analysis of variance. We ran pairwise tests for multiple comparisons of diaspores composition variation among bird species. Principal coordinates analysis (also called metric multidimensional scaling) is a multivariate method (unconstrained ordination) that attempts to summarise (dis-) similarity among a set of samples in a few dimensions. This analysis produces a set of orthogonal axes whose importance is measured by eigenvalues (Borcard, Gillet, \& Legendre, 2018; Lepš \& Šmilauer, 2003). To conduct principal coordinates analysis and to plot the ordination, we use the $\mathrm{R}$ functions cmdscale and ordiplot from package vegan in the $R$ statistical environment v. 3.6.1 ( $R$ Development Core Team, 2019).

We used indicator species analysis (Dufrêne \& Legendre, 1997) to determine which diaspores species discriminated between bird species and seasons. The significance of the observed maximum indicator value (IV) for species was derived from 9,999 permutations in R. Finally, we measured diaspore length and classified them into six categories ( $\leq 0.5 \mathrm{~mm}, 0.51-1 \mathrm{~mm}, 1.1-1.5 \mathrm{~mm}, 1.51-2 \mathrm{~mm}, 2.1-$ $2.5 \mathrm{~mm},>2.5 \mathrm{~mm}$ ) in order to analyse differences among waterfowl species in the size of diaspores dispersed. We measured five diaspores from each taxon (or all of them when $n<5$ ), and used mean values.

\section{3 | RESULTS}

\section{1 | Plant taxa dispersed by endozoochory}

We found 2,066 intact diaspores from 40 plant taxa, 31 of which were identified to species level, five to genus and four to family (Table S1). We found diaspores of 37 angiosperms, plus megaspores (Lycophyta-Isoetes cf. maxima), sporocarps (Pteridophyta-Azolla filiculoides) and oogonia (Charophyceae). Twenty-nine of the identified species are native to Brazil and two are alien but considered naturalised (Echinochloa cruss-galli and Salicornia fruticosa). Five species (Cyperus difformis, E. cruss-galli, Heteranthera reniformis, Ludwigia erecta and Panicum dichotomiflorum) are rice weeds (Table S1). Eight species are terrestrial, nine amphibious and 15 are aquatic plants (Table S1). Habitat classification of the other eight taxa was not possible (Table S1). Of the aquatic and amphibious plants (24 spp), 15 were emergent, four fixed-floating, one free-floating ( $A$. filiculoides), and four submergent (Table S1).

In $65 \%$ of all faecal samples, there was at least one diaspore ( $77 \%$ of samples in the cold period and $51 \%$ in the warm period). Each sample contained a median of two diaspores in the cold period (interquartile range: 10,25), ranging from samples without diaspores to a sample from yellow-billed teal that contained 489 seeds of Rynchospora sp. In the warm period, the median number of diaspores per sample was one (interquartile range: 3,0 ), with a range of 0-33 diaspores. Cyperaceae (12 taxa) and Poaceae (8) were the most diverse families. We found 1,835 diaspores (from 33 taxa) in the cold period and 231 ( 23 taxa) in the warm period. Seventeen taxa
TABLE 1 Analysis of deviance of the best fitted model with the effects of the factors bird species, season, and sample weight, demonstrating that interaction between species and seasons had a particularly strong effect on the richness and abundance of diaspores dispersed by waterfowl

\begin{tabular}{|llrrr|} 
Variable & Factor & LR Chisq & $d f$ & $p$-value \\
\hline Richness & Bird & 10.712 & 4 & 0.030 \\
& Season & 5.628 & 1 & 0.018 \\
& Weight & 6.905 & 1 & 0.009 \\
Abundance & Bird*Season & 23.044 & 4 & $<0.001$ \\
& Bird & 44.821 & 4 & $<0.001$ \\
& Season & 20.273 & 1 & $<0.001$ \\
& Weight & 2.809 & 1 & 0.094 \\
& Bird*Season & 18.920 & 4 & $<0.001$ \\
\hline
\end{tabular}

Note: The model fitted through generalised linear model analysis for both richness and abundance included all factors investigated: richness (or abundance) $\sim$ Bird + Season + Weight + Bird*Season. See Table S2 for further details.

(42.5\% of the total) were recorded only in the cold period, and seven (17.5\%) only in the warm period, with $16(40 \%)$ common to both periods. The grass Zizaniopsis bonariensis and the sedge Rynchospora sp. were the most abundant taxa recorded, representing $50 \%$ of all diaspores (Table S1). Zizaniopsis bonariensis was also the most frequently recorded species ( $20 \%$ of samples), followed by Oldenlandia salzmannii (17\%), Eleocharis minima (12\%), and Nymphoides indica (12\%). Zizaniopsis bonariensis was present in samples obtained in three wetlands in the cold period, and four wetlands in the warm period. Rynchospora sp., was recorded only during the cold period, in samples from two wetlands.

\section{2 | Effects of bird species, sample weight, and seasonality on plant taxon richness and diaspore abundance}

The best fit models considered all variables tested and showed that the interaction between bird species and season was the most important effect explaining taxonomic richness and abundance of diaspores ( $p<0.05$; Table 1). In the case of diaspore abundance, there were two other models with $\triangle \mathrm{AIC}<2$ (Table S3).

In the warm period, Brazilian teal dispersed a significantly lower richness of diaspores than all other birds ( $p<0.05$ ), except the coscoroba swan ( $p>0.05$; Figure 1, Table S4). In the cold period, white-faced whistling-duck dispersed a lower richness than Brazilian teal, ringed teal, and yellow-billed teal $(p<0.05)$. In the warm period, Brazilian teal and coscoroba swan dispersed significantly fewer diaspores per sample than other bird species $(p<0.05)$, with no difference between them ( $p>0.05$; Figure 2 , Table S4). In the cold period, ringed teal dispersed more diaspores per sample than other bird species, and yellow-billed teal dispersed more diaspores than Brazilian teal and white-faced whistling-duck $(p<0.05)$. 


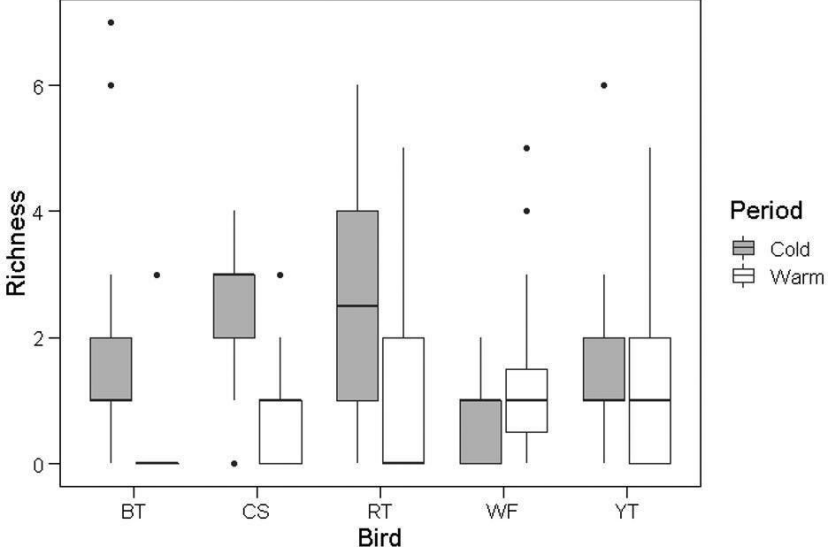

FIGURE 1 Seasonal variation in taxonomic richness of diaspores dispersed by waterfowl species. BT, Brazilian teal; YT, yellowbilled teal; RT, ringed teal; CS, coscoroba swan; WF, white-faced whistling-duck. Boxes represent the range of quartiles Q2 and Q3 separated by the median (bold horizontal lines). Vertical lines indicate maximum and minimum limits of Q1 and Q4, while dots represent outliers

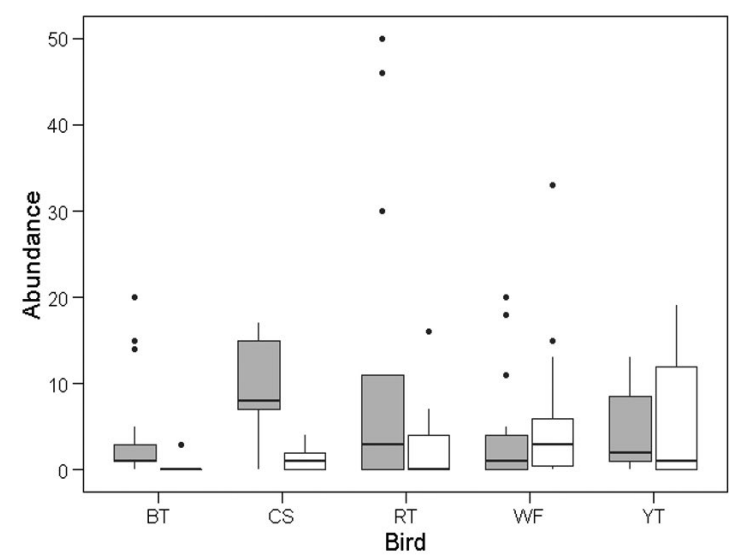

FIGURE 2 Seasonal variation in abundance of diaspores among waterfowl species. BT, Brazilian teal; YT, yellow-billed teal; RT, ringed teal; CS, coscoroba swan; WF, white-faced whistling-duck. Boxes represent the range of quartiles Q2 and Q3 separated by the median (bold horizontal lines). Vertical lines indicate maximum and minimum limits of Q1 and Q4, while dots represent outliers. We excluded outliers greater than 50 diaspores per sample (five of ringed teal and one of yellow-billed teal) to improve the visualisation of differences between species

\subsection{Variation in the taxonomic composition of diaspores between vectors}

The taxonomic composition of diaspores dispersed differed significantly among waterfowl species $\left(r^{2}=0.10, F_{4,102}=2.874, p<0.05\right)$ and seasons $\left(r^{2}=0.02, F_{1,105}=2.829, p<0.05\right.$; Figure 3a,b). Diaspore composition varied significantly between coscoroba swan and ringed teal, and between them and all other species. The composition of diaspores dispersed by Brazilian teal, white-faced whistlingduck, and yellow-billed teal was not significantly different (Table S5). (a)

Bird species

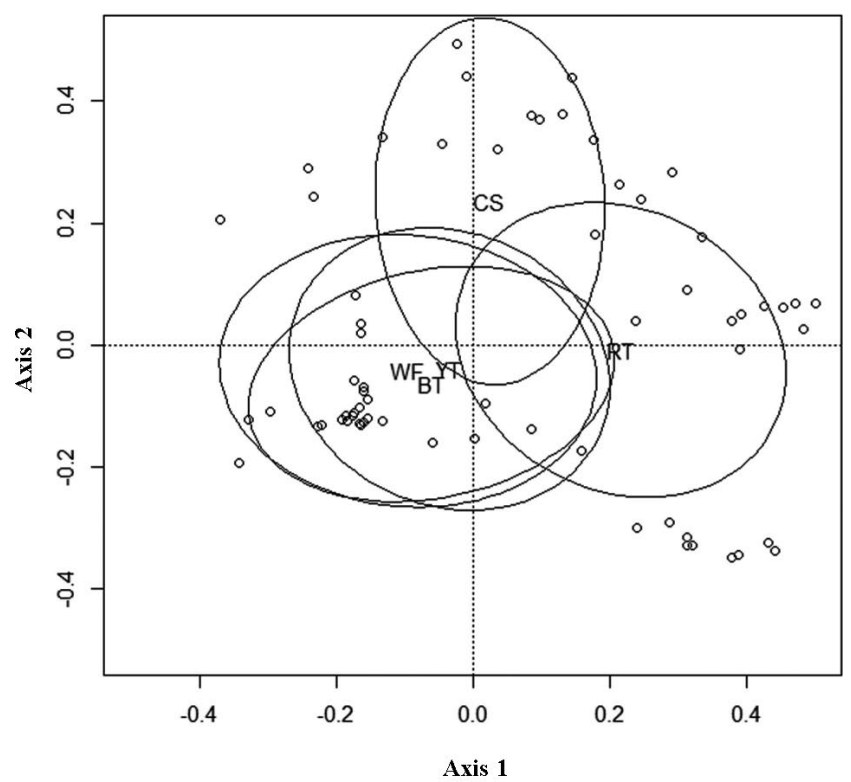

(b)

Seasons

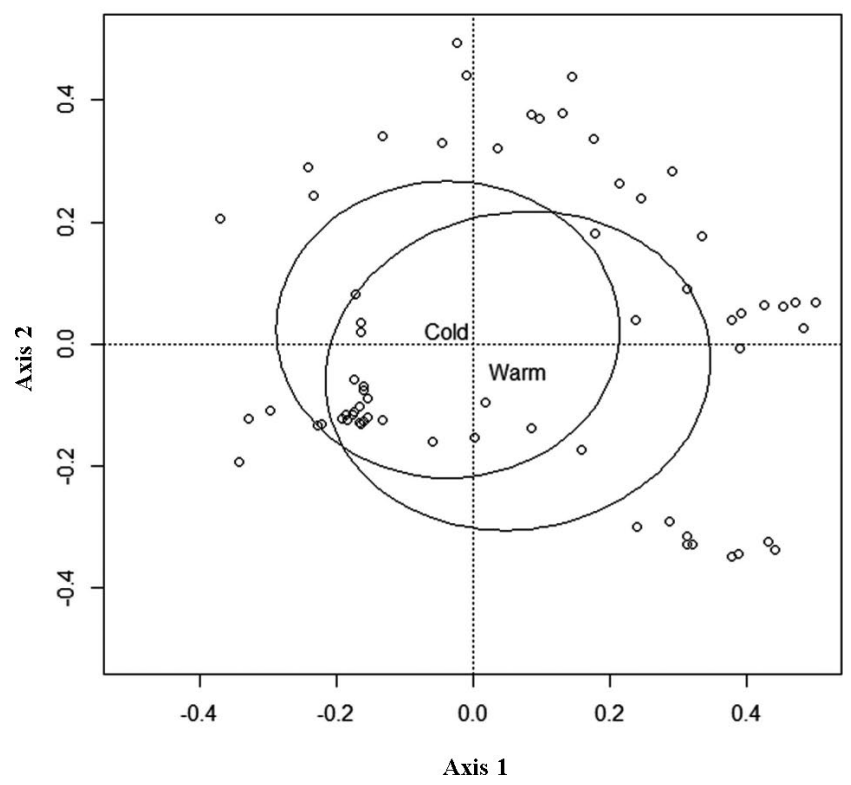

FIGURE 3 Ordination of taxonomic composition of diaspores, and how it varied among (a) bird species, and (b) cold and warm periods. The total variation explained by the axes was 32\% (Axis $1=17 \%$ and Axis $2=15 \%$ ). Bird species are represented by the initials BT, Brazilian teal; YT, yellow-billed teal; RT, ringed teal; CS, coscoroba swan; WF, white-faced whistling-duck

Hence the largest (coscoroba swan) and smallest (ringed teal) birds were different to those of intermediate size (Figure 3a).

\section{4 | Dispersal interactions between particular plant and bird species}

Seeds of Echinochloa crussgalli (IV $=0.200$ ), Eleocharis flavescens (IV $=0.220$,) and Panicum germinatum (IV $=0,150$ ) were associated 
with Brazilian teal $(p<0.05)$. Seeds of Hydrocleys nymphoides and those from fleshy fruits of Rubiaceae spp. were associated with coscoroba swan (IV $=0.368$ and IV $=0.160$, respectively; $p<0.05$ ). Apocynaceae spp. (IV $=0.197 ; p<0.05)$ was associated with whitefaced whistling-duck and Potamogeton pusillus (IV $=0.237 ; p<0.05$ ) with yellow-billed teal. Seeds of O. salzmannii (IV $=0.487$ ), E. minima (IV = 0.451), Z. bonariensis (IV = 0.439), Kyllinga odorata (IV = 0.200), and Eleocharis bonariensis (IV $=0.225$ ) were more prevalent and abundant in samples from ringed teal $(p<0.05)$. Apocynaceae spp. (IV $=0.165 ; p<0.05$ ) was mainly dispersed in the warm period and E. flavescens (IV $=0.130 ; p<0.05$ ) in the cold period.

The average length of diaspores dispersed by waterfowl was 1.30 $\pm 0.74 \mathrm{~mm}$. Diaspores with length up to $1.5 \mathrm{~mm}$ accounted for $94.3 \%$ of the diaspores recorded and were predominant in all bird species (Table S6, Figure 4). Only white-faced whistling-duck and coscoroba swan dispersed diaspores from all length categories, with coscoroba swan having the highest value for size categories above $2 \mathrm{~mm}$ (8.2\%).

\section{4 | DISCUSSION}

To our knowledge, we have conducted the most detailed study to date of endozoochory by any animal in the neotropics from outside forested environments, and the first study comparing endozoochory by different waterbirds in neotropical wetlands. Our results demonstrate that all five neotropical waterfowl species are important plant vectors, dispersing at least 40 different plant species.

\subsection{What plants are dispersed?}

The most frequently dispersed seeds were of $Z$. bonariensis, an emergent giant grass considered Vulnerable in Brazil due to habitat loss. Z. bonariensis occurs in isolated populations in southeast and southern Brazil, Argentina, Paraguay, and Uruguay and is considered to disperse primarily by anemochory and vegetative propagation (CNCFlora, 2012; Ferreira, Van Nes, \& Marques, 2009). Our results suggest that endozoochory by waterfowl has an important but previously unrecognised role in the distribution of $Z$. bonariensis. The second most dispersed plant genus, Rynchospora sp., is widely distributed in the region, notably R. barrosiana, $R$. brittonii, and $R$. tenuis (Weber, 2014), and this may be related to their capacity for frequent dispersal by waterfowl. The plant families Poaceae and Cyperaceae had the highest taxonomic richness, following a pattern reported in previous studies on Anatidae in other continents (Green et al., 2016; Reynolds \& Cumming, 2016a, 2016b; de Vlaming \& Proctor, 1968).

The diaspores dispersed by waterfowl varied from strictly aquatic plants (e.g. Ruppia maritima) to amphibious (interface between aquatic and terrestrial, e.g. E. flavescens) and terrestrial (e.g. Solanum americanum) plants. This is consistent with recent studies in Europe showing that ducks and shorebirds are important vectors for both aquatic and terrestrial plants (Lovas-Kiss et al., 2018, 2019; Soons, Brochet, Kleyheeg, \& Green, 2016). The dominant diaspores were those of angiosperms lacking a fleshy fruit, and most of these angiosperm species are widely considered to be self-dispersed or dispersed by water (hydrochory), and hence to have no mechanisms for dispersal between isolated wetlands. Because they lack a fleshy fruit, the importance of endozoochory for these plants is consistently overlooked in the literature and in plant trait databases (Costea et al., 2019; Soons et al., 2016). On the other hand, we record two plant taxa with fleshy fruits (S. americanum and Rubiaceae spp.), which are therefore considered to have an endozoochory syndrome. These findings reinforce the important function of waterfowl endozoochory in the dispersal of a broad taxonomic range of plants, in line with studies from other continents (Green et al., 2016; LovasKiss et al., 2018; Reynolds \& Cumming, 2016a, 2016b).

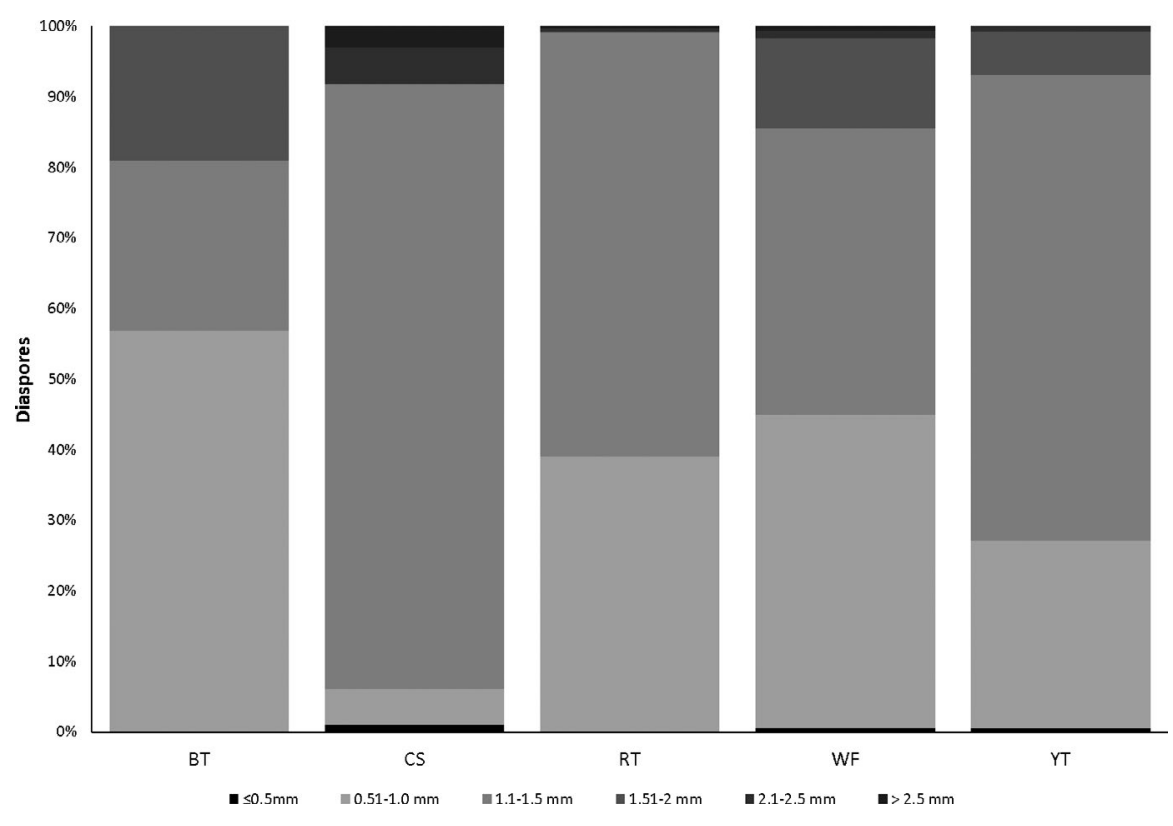

FIGURE 4 Percentage composition of diaspores per waterfowl species. BT, Brazilian teal; YT, yellow-billed teal; RT, ringed teal; CS, coscoroba swan; WF, white-faced whistling-duck 
We also found quillwort megaspores (Isoetes cf. maxima) and sporocarps of floating ferns (A. filiculoides) to be dispersed by waterfowl. Dispersal by endozoochory has been proposed as an explanation for the distribution of quillworts (Brunton \& Britton, 1999; Troia, 2016), but this has not previously been demonstrated. The fern A. filiculoides is native in our study area and an invasive alien species in other continents (Hill, Coetzee, Martin, Smith, \& Strange, 2020; Hussner, 2012), and it has often been suggested that it may spread by zoochory (Lovas-Kiss et al., 2018; Reynolds, Miranda, \& Cumming, 2015). Coughlan, Cuthbert, Kelly, and Jansen (2018) demonstrated experimentally that $A$. filiculoides can survive external transport by waterfowl. Green, Jenkins, Bell, Morris, and Kingsford (2008) found reproductive tissue in the faeces of Australian waterbirds, highlighting the possibility of internal transport. We found that intact diaspores of $A$. filiculoides after waterfowl gut passage, confirming its dispersal by endozoochory.

\section{2 | Dispersal depends on seasonality and bird species}

The interaction between bird species and season explained the most variance in plant taxonomic richness and diaspore abundance in our study. Figuerola et al. (2003) found a similar result for endozoochory by wintering waterbirds in Spain. These authors argued that changes in the richness and abundance of diaspores dispersed were related to species-specific seasonal variations in diet, feeding behaviour, and digestive processing of food. Our findings are likely to have similar explanations, but there is a general lack of detailed studies of diet and feeding behaviour in neotropical waterfowl. In one exception, Madriz (1983) found seasonal variation in the frequency of different seeds observed in oesophagi of Brazilian teal in Venezuela, with increased seed ingestion in the rainy season.

The diaspore composition of coscoroba swan and ringed teal faeces was different from that of the other three species, although the proportion of the variation explained by species was relatively low, suggesting that there is much overlap as also reported for Europe (Figuerola et al., 2003; Green et al., 2016). The variation we recorded may be related to the differences in the body size and its influence on foraging behaviour. Coscoroba swan is larger (c. 3,500 g) and ringed teal smaller (c. $350 \mathrm{~g}$ ) than the other species (500-800 g; Kear, 2005a, 2005b). These extremes in body size and associated differences in access to different depths for feeding may lead to greater habitat segregation, and hence access to diaspores of different plants (Green, 1998; Guillemain, Fritz, Guillon, \& Simon, 2002; Ntiamoa-Baidu et al., 1998; Pöysä, 1983). In our study, we observed coscoroba swan feeding in the deepest areas, ringed teal in the shallowest areas, and the other three species usually feeding together elsewhere. These field observations suggest that body size may be a determinant of diaspores ingestion. In future, the influence of body size on diaspore dispersal should be further investigated in neotropical waterbirds, with the inclusion of more bird species with different body sizes, and detailed field observations of feeding behaviour and plant ecology (in a manner paralleling the many detailed studies of frugivore behaviour in neotropical forests).

Coscoroba swan dispersed the largest proportion, 8.2\%, of large seeds (i.e. $>2 \mathrm{~mm}$ ). This could potentially be because large seeds were less likely to be destroyed in the larger birds (García-Alvarez et al., 2015), but may alternatively be due to a negative relation between body size and the density of lamellae in the bill, which have a key role in food processing (Gurd, 2008). High lamellae density facilitates selection of smaller seeds, and this explains for example why the Eurasian teal Anas crecca ingests smaller seeds than larger dabbling ducks in Europe (Green et al., 2016; Guillemain et al., 2002). However, we lack data on lamellar density in our study species to test this hypothesis.

The phenology of seed availability may lead to differences in richness and abundance of dispersed diaspores in temperate waterbirds (Clausen et al., 2002; Green, Figuerola, \& Sánchez, 2002; Lovas-Kiss et al., 2019). A lack of information on plant phenology in our study area prevented us from making a detailed analysis of relationships between seasonal variation in seed production and seed dispersal. However, data for 15 plant species dispersed in our study, but obtained previously in similar regions of the extreme south of Brazil, show that some plants produce seeds exclusively in the cold or the warm period and others in both periods (Giehl, 2012; Trevisan, 2005). These data confirm that some species were dispersed exclusively in the period when they would be producing seeds, e.g. $N$. indica in the cold period and $H$. nymphoides in the warm period. However, other plants such as $S$. fruticosa (dispersed in the warm period) and L. erecta (dispersed in both periods) were dispersed in a different season to those when seeds are produced (according to the above literature). Thus, future research into seed production and seed availability in the water column and in sediments is needed to understand how they influence dispersal rates in neotropical wetlands.

\subsection{Pathways for plant dispersal in the southern half of South America}

Information about flight patterns, migration routes, population size, and distributions of the study waterfowl species is limited compared with North America or Europe. However, the available information gives us some indication about the relationships between functional and behavioural variations and the dispersal potential (DP, sensu Coughlan et al., 2019) of each bird species. Experimental studies have shown that seeds are typically retained in waterfowl guts for at least 4-8 hr and often for much longer, with maxima frequently exceeding 24 hr (García-Alvarez et al., 2015; Lovas-Kiss et al., 2020; Reynolds \& Cumming, 2016a, 2016b). Given flight speeds of $50-78 \mathrm{~km} / \mathrm{hr}$ (Welham, 1994), this enables seed dispersal by endozoochory over tens or hundreds of km during daily or migratory flights, greatly exceeding the maximum dispersal distances obtained by wind or water dispersal for most plant species, which rarely reach $1 \mathrm{~km}$ (Bullock et al., 2017). 
Coscoroba swan and white-faced whistling duck are the most migratory species, ringed teal and yellow-billed teal are residents with occasional regional movements, and Brazilian teal are typical residents (Belton, 1994; Calabuig et al., 2010; Don Pablo Research Team, 2012; Maurício et al., 2013). In this sense, coscoroba swan has the higher potential to disperse plants over the greatest distances among the study species, mainly in an east-west direction. This swan has an estimated population of $10,000-25,000$ individuals distributed across a range of $4,250,000 \mathrm{~km}^{2}$ (BirdLife International, 2020; Wetlands International, 2020). In southern Brazil, the most recent census was of 1,622 individuals (Dias \& Fontana, 2002) with a partially migratory population, most of which leaves the study area in the warm period in an east-west route towards Argentina, moving up to $1,700 \mathrm{~km}$, and then returning in the cold period (Calabuig et al., 2010). Nevertheless, coscoroba swan is also likely to disperse plants in a north-south direction, inside the continent, since part of its population is migratory both in the northern (Pantanal and Chaco to Pampa) and in the southern (Patagonia to Pampa) parts of its range (Carboneras, 2019).

White-faced whistling duck is partially migratory in the neotropics, with an estimated population of 1,000,000 individuals distributed over up to $10,000,000 \mathrm{~km}^{2}$ (BirdLife International, 2020; Wetlands International, 2020). Southern Brazil has a partially migratory population of about 100,000 individuals (Menegheti \& Dotto, 2004) that use the east-west route. In central South America white-faced whistling migrates along a north-south flyway along the Paraná-Paraguay rivers (Blanco, Fletcher, Lesterhuis, \& Petracci, 2020). Satellite tracking data from birds fitted with transmitters in Argentina found them to move up to $>600 \mathrm{~km}$ away from the capture site, with individuals having daily average movements of 0.1-23 km (mean of 4 km; Don Pablo Research Team, 2012). There was great individual variability in the timing and direction of movements, with some individuals moving to Brazil, Uruguay, or Paraguay.

Some ringed teal make regional north-south seasonal movements between southern Brazil and Uruguay, with irregular routes, and there are also resident populations along this route (Belton, 1994; Maurício et al., 2013, Carboneras et al., 2019). The range of ringed teal is $2,270,000 \mathrm{~km}^{2}$ with an estimated population of 25,000100,000 (BirdLife International, 2020; Wetlands International, 2020). Satellite tracking data from birds fitted with transmitters in Argentina (Don Pablo Team, 2017) showed that ringed teal moved to locations an average of $238 \mathrm{~km}$ from their capture site (min: $9 \mathrm{~km}$, $\max : 423 \mathrm{~km})$.

Brazilian teal and yellow-billed teal are thought to be resident species that disperse mainly between local wetlands, but there are few data on their movements (Nascimento, Koch, Efe, \& Scherer, 2005; Carboneras et al., 2019). They are both abundant (about $1,000,000$ individuals per species) with a similar range size (about $12,500,000 \mathrm{~km}^{2}$ ), but contrasting distributions (yellow-billed teal from central to southern South America and Brazilian teal from the central to the north).

The DP of each species depends on both the number of diaspores dispersed per individual and the population size (Coughlan et al., 2019), and our results show it also varies seasonally. In the cold season, the greater abundance of diaspores per bird suggests that ringed teal has the highest DP at a local scale, although we are lacking precise population estimates for our study area. At the continental scale, its high population size and intermediate number of diaspores per individual suggest that yellow-billed teal has the highest DP.

\section{4 | Conclusion}

We demonstrated that the five waterfowl species studied play an important role in the dispersal of a broad variety of plants, ranging from strictly aquatic to terrestrial species, and including both native and exotic plants. The interaction between bird species and seasonality explained the most variation in diaspores dispersed. The composition of diaspores dispersed varied between seasons and between three groups of bird species. The scarcity of studies on the phenology of plants and waterfowl movements currently limits our understanding of spatial and temporal patterns of endozoochory in the neotropical region. However, our study demonstrates that this process is important at different spatial scales, and is likely to be central to the maintenance of plant metacommunities and to changes in plant distributions in the face of global change.

\section{ACKNOWLEDGMENTS}

G.G.S. thanks CAPES for a doctoral scholarship and Fabio Cavitione for help with field expeditions and sample collection. L.M. and C.S. hold Research Productivity Grants from CNPq. This research was supported by funds from UNISINOS (grant no. 02.00.023/00-0) and CNPq (grant no. 52370695-2). A.J.G. was supported by Spanish National Plan project CGL2016-76067-P (AEI/FEDER, EU). Á.L-K was supported by the New National Excellence Programme of the Ministry of Innovation and Technology ÚNKP-19-4-DE-172, by the János Bolyai Research Scholarship of the Hungarian Academy of Sciences, and by the NKFIH OTKA FK-127939 and KH-129520 grants.

\section{DATA AVAILABILITY STATEMENT}

A summary of the data used in this paper is available as Supporting Information.

\section{ORCID}

Giliandro G. Silva iD https://orcid.org/0000-0001-5903-4043

Andy J. Green (iD https://orcid.org/0000-0002-1268-4951

Pedro Hoffman (iD https://orcid.org/0000-0002-6705-1916

Vinícius Weber (iD https://orcid.org/0000-0003-4554-6413

Cristina Stenert iD https://orcid.org/0000-0002-9095-2018

Ádám Lovas-Kiss (iD https://orcid.org/0000-0002-8811-1623

Leonardo Maltchik iD https://orcid.org/0000-0002-5321-7524

\section{REFERENCES}

Bartel, R. D., Sheppard, J. L., Lovas-Kiss, Á., \& Green, A. J. (2018). Endozoochory by mallard in New Zealand: What seeds are 
dispersed and how far? PeerJ, 6, e4811. https://doi.org/10.7717/ peerj.4811

Belton, W. (1994). Aves do Rio Grande do Sul: Distribuição e Biologia. São Leopoldo, Brazil: Unisinos.

BirdLife International (2020). IUCN Red List for birds. Retrieved from http://www.birdlife.org on 19 June 2020.

Blanco, D., Fletcher, A., Lesterhuis, A., \& Petracci, P. (2020). Corredor de aves migratorias del sistema Paraguay-Paraná. Programa Corredor Azul. Buenos Aires, Argentina: Fundación Humedales/Wetlands International.

Borcard, D., Gillet, F., \& Legendre, P. (2018). Numerical ecology with R (2nd ed.). New York, NY: Springer.

Brochet, A. L., Guillemain, M., Fritz, H., Gauthier-Clerc, M., \& Green, A. J. (2010). Plant dispersal by teal (Anas crecca) in the Camargue: Duck guts are more important than their feet. Freshwater Biology, 55(6), 1262-1273. https://doi.org/10.1111/j.1365-2427.2009.02350.x

Brunton, D. F., \& Britton, D. M. (1999). Maritime quillwort, Isoetes maritima (Isoetaceae), in the Yukon territory. Canadian Field Naturalist, 113(4), 641-645.

Bullock, J. M., Gonzalez, L. M., Tamme, R., Gotzenberger, L., White, S. M., Partel, M., ... Hooftman, D. A. P. (2017). A synthesis of empirical plant dispersal kernels. Journal of Ecology, 105, 6-19. https://doi. org/10.1111/1365-2745.12666

Burnham, K. P., \& Anderson, D. R. (2002). A practical information-theoretic approach. Model selection and multimodel inference (2nd ed.). New York, NY: Springer.

Calabuig, C. P., Green, A. J., Menegheti, J. O., Muriel, R., \& PatiñoMartínez, J. (2010). Fenología del coscoroba (Coscoroba coscoroba) en el sur de Brasil y sus movimientos hacia Argentina. Ornitologia Neotropical, 21, 555-566.

Carboneras, C. (2019). Ducks, Geese, Swans (Anatidae). In J. del Hoyo, A. Elliott, J. Sargatal, D. A. Christie, \& E. de Juana (Eds.), Handbook of the birds of the world alive. Barcelona, Spain: Lynx Edicions. Retrieved from https://www.hbw.com/node/52210 on 17 November 2019.

Clausen, P., Nolet, B. A., Fox, A. D., \& Klaassen, M. (2002). Long-distance endozoochorous dispersal of submerged macrophyte seeds by migratory waterbirds in northern Europe - A critical review of possibilities and limitations. Acta Oecologica, 23(3), 191-203. https://doi. org/10.1016/S1146-609X(02)01150-5

CNCFlora(2012). Zizaniopsis bonariensis in Lista Vermelha da flora brasileira versão 2012.2. Centro Nacional de Conservação da Flora. Retrieved from http://cncflora.jbrj.gov.br/portal/pt-br/profile/Zizan iopsis bonariensis on 9 June 2020.

Costea, M., El Miari, H., Laczkó, L., Fekete, R., Molnár, A. V., Lovas-Kiss, Á., \& Green, A. J. (2019). The effect of gut passage by waterbirds on the seed coat and pericarp of diaspores lacking "external flesh": Evidence for widespread adaptation to endozoochory in angiosperms. PLoS One, 14(12), e0226551. https://doi.org/10.1371/journal.pone.0226551

Costea, M., Stefanović, S., García, M. A., De La Cruz, S., Casazza, M. L., \& Green, A. J. (2016). Waterfowl endozoochory: An overlooked long-distance dispersal mode for Cuscuta (dodder). American Journal of Botany, 103(5), 957-962. https://doi.org/10.3732/ ajb.1500507

Coughlan, N. E., Cuthbert, R. N., Kelly, T. C., \& Jansen, M. A. (2018). Parched plants: Survival and viability of invasive aquatic macrophytes following exposure to various desiccation regimes. Aquatic Botany, 150, 9-15. https://doi.org/10.1016/j.aquabot.2018.06. 001

Coughlan, N. E., Dickey, J. W., Cuthbert, R. N., Kelly, T. C., Jansen, M. A., \& Dick, J. T. (2019). Driver's seat: Understanding divergent zoochorous dispersal of propagules. Frontiers in Ecology and Evolution, 7, 70. https://doi.org/10.3389/fevo.2019.00070

Coughlan, N. E., Kelly, T. C., Davenport, J., \& Jansen, M. A. K. (2017). Up, up and away: Bird-mediated ectozoochorous dispersal between aquatic environments. Freshwater Biology, 62, 631-648. https://doi. org/10.1111/fwb.12894

de Vlaming, V., \& Proctor, V. W. (1968). Dispersal of aquatic organisms: Viability of seeds recovered from the droppings of captive killdeer and mallard ducks. American Journal of Botany, 55(1), 20-26. https:// doi.org/10.1002/j.1537-2197.1968.tb06939.x

Dias, R. A., \& Fontana, C. S. (2002). Distribuição, biologia, ecologia e conservação do cisne-de-pescoço-preto Cygnus melanocorypha, e da capororoca Coscoroba coscoroba, no Brasil. In S.M. Seijas (Ed.), Censo Neotropical de Cisnes: Conteo de Cisnes de Cuello Negro (Cygnus melancoryphus) y Coscorobas (Coscoroba coscoroba) en Argentina, Brasil y Uruguay. Periodo 1998-2000. (pp. 1-20). Buenos Aires, Argentina: L.O.L.A

Don Pablo Research Team. (2012). Movements and resource utilization of four species of ducks captured in the mid-Parana River Basin, Corrientes Province, Argentina (p. 115). Cambridge, MD: USGS.

Don Pablo Research Team. (2017). History and status - July 2014 to January 2017 radio telemetry tracking of ringed teal by Don Pablo Research Team. Technical Report.

Dufrêne, M., \& Legendre, P. (1997). Species assemblages and indicator species: The need for a flexible asymmetrical approach. Ecological Monographs, 67(3), 345-366. https://doi.org/10.1890/00129615(1997)067[0345:SAAIST]2.0.CO;2

Farmer, J. A., Webb, E. B., Pierce, R. A., \& Bradley, K. W. (2017). Evaluating the potential for weed seed dispersal based on waterfowl consumption and seed viability. Pest Management Science, 73(12), 2592-2603. https://doi.org/10.1002/ps.4710

Ferreira, T. F., Van Nes, E. H., \& Marques, D. M. (2009). Continuous growth of the giant grass Zizaniopsis bonariensis in subtropical wetlands. Freshwater Biology, 54(2), 321-330. https://doi. org/10.1111/j.1365-2427.2008.02110.x

Figuerola, J., \& Green, A. (2002). Dispersal of aquatic organisms by waterbirds: A review of past research and priorities for future studies. Freshwater Biology, 47, 483-494. https://doi. org/10.1046/j.1365-2427.2002.00829.x

Figuerola, J., Green, A. J., \& Santamaría, L. (2003). Passive internal transport of aquatic organisms by waterfowl in Doñana, south-west Spain. Global Ecology and Biogeography, 12(5), 427-436. https://doi. org/10.1046/j.1466-822X.2003.00043.x

Galetti, M., Keuroghlian, A., Hanada, L., \& Morato, M. I. (2001). Frugivory and Seed Dispersal by the Lowland Tapir (Tapirus terrestris) in Southeast Brazil 1. Biotropica, 33(4), 723-726. https://doi. org/10.1111/j.1744-7429.2001.tb00232.x

García-Alvarez, A., van Leeuwen, C. H. A., Luque, C. J., Hussner, A., Velez-Martin, A., Perez-Vazquez, A., ... Castellanos, E. M. (2015). Internal transport of alien and native plants by geese and ducks: An experimental study. Freshwater Biology, 60, 1316-1329. https://doi. org/10.1111/fwb.12567

Giehl, E. L. H. (2012). Flora digital do Rio Grande do Sul e de Santa Catarina. UFRGS. Retrieved from http://www.ufrgs.br/fitoecologia/ florars/.

Green, A. J. (1998). Comparative feeding behaviour and niche organization in a Mediterranean duck community. Canadian Journal of Zoology, 76(3), 500-507. https://doi.org/10.1139/z97-221

Green, A. J., \& Elmberg, J. (2014). Ecosystem services provided by waterbirds. Biological Reviews, 89(1), 105-122. https://doi.org/10.1111/ brv.12045

Green, A. J., Figuerola, J., \& Sánchez, M. I. (2002). Implications of waterbird ecology for the dispersal of aquatic organisms. Acta Oecologica, 23(3), 177-189. https://doi.org/10.1016/S1146-609X(02)01149-9

Green, A. J., Frisch, D., Michot, T. C., Allain, L. K., \& Barrow, W. C. (2013). Endozoochory of seeds and invertebrates by migratory waterbirds in Oklahoma, USA. Limnetica, 32(1), 39-46.

Green, A. J., Jenkins, K. M., Bell, D., Morris, P. J., \& Kingsford, R. T. (2008). The potential role of waterbirds in dispersing invertebrates and 
plants in arid Australia. Freshwater Biology, 53, 380-392. https://doi. org/10.1111/j.1365-2427.2007.01901.x

Green, A. J., Soons, M., Brochet, A. L., \& Kleyheeg, E. (2016). Dispersal of plants by waterbirds. Chapter Six. In Ç. H. Sekercioglu, D. G. Wenny, \& C. J. Whelan (Eds.), Why birds matter: Avian ecological function and ecosystem services (pp. 107-145). Chicago, IL: University of Chicago Press.

Guadagnin, D. L., \& Maltchik, L. (2007). Habitat and landscape factors associated with neotropical waterbird occurrence and richness in wetland fragments. Biodiversity and Conservation, 16, 1231-1244. https://doi.org/10.1007/978-1-4020-6320-6_27

Guadagnin, D. L., Maltchik, L., \& Fonseca, C. R. (2009). Species-area relationship of Neotropical waterbird assemblages in remnant wetlands: Looking at the mechanisms. Diversity and Distributions, 15, 319-327. https://doi.org/10.1111/j.1472-4642.2008.00533.x

Guadagnin, D. L., Peter, A., Rolon, A. S., Stenert, C., \& Maltchik, L. (2012). Does non-intentional flooding of rice fields after cultivation contribute to waterbirds conservation in Southern Brazil? Waterbirds, 35, 371-380. https://doi.org/10.1675/063.035.0302

Guillemain, M., Fritz, H., Guillon, N., \& Simon, G. (2002). Ecomorphology and coexistence in dabbling ducks: The role of lamellar density and body length in winter. Oikos, 98(3), 547-551. https://doi. org/10.1034/j.1600-0706.2002.980321.x

Gurd, D. B. (2008). Mechanistic analysis of interspecific competition using foraging trade-offs: Implications for duck assemblages. Ecology, 89, 495-505. https://doi.org/10.1890/06-1545.1

Hattermann, D., Bernhardt-Römermann, M., Otte, A., \& Eckstein, R. L. (2019). Geese are overlooked dispersal vectors for vascular plants in archipelago environments. Journal of Vegetation Science, 30(3), 533-541. https://doi.org/10.1111/jvs.12742

Heleno, R., \& Vargas, P. (2015). How do islands become green? Global Ecology and Biogeography, 24(5), 518-526. https://doi.org/10.1111/ geb.12273

Hill, M. P., Coetzee, J. A., Martin, G. D., Smith, R., \& Strange, E. F. (2020). Invasive alien aquatic plants in South African freshwater ecosystems. In B. W. van Wilgen J. Measey D.M. Richardson J.R. Wilson \& T.A. Zengeya(Eds.), Biological invasions in South Africa (pp. 97-114). Cham: Springer.

Hussner, A. (2012). Alien aquatic plant species in European countries. Weed Research, 52(4), 297-306. https://doi. org/10.1111/j.1365-3180.2012.00926.x

Kear, J. (2005a). Ducks, geese and swans: Special accounts (Anhima to Salvadorina). Oxford, UK: Oxford University Press.

Kear, J. (2005b). Ducks, geese and swans: Species accounts (Cairina to Mergus). Oxford, UK: Oxford University Press.

Kleyheeg, E., Treep, J., de Jager, M., Nolet, B. A., \& Soons, M. B. (2017). Seed dispersal distributions resulting from landscape-dependent daily movement behaviour of a key vector species, Anas platyrhynchos. Journal of Ecology, 105, 1279-1289. https://doi. org/10.1111/1365-2745.12738

Kleyheeg, E., Fiedler, W., Safi, K., Waldenstrom, J., \& van Toor, van Toor (2019). A Comprehensive Model for the Quantitative Estimation of Seed Dispersal by Migratory Mallards. Frontiers in Ecology and Evolution, 7, https://doi.org/10.3389/fevo.2019.00040.

Lepš, J., \& Šmilauer, P. (2003). Multivariate analysis of ecological data using Canoco. Cambridge, UK: Cambridge University Press.

Levey, D. J., Silva, W. R., \& Galetti, M. (2002). Seed dispersal and frugivory: Ecology, evolution, and conservation. Wallingford, UK: CAB International.

Lomolino, M. H., Riddle, B. R., Whittaker, R. J., \& Brown, J. H. (2010). Biogeography (4th ed.). Sunderland, MA: Sinauer Associates.

Lovas-Kiss, Á., Sánchez, M. I., Wilkinson, D. M., Coughlan, N. E., Alves, J. A., \& Green, A. J. (2019). Shorebirds as important vectors for plant dispersal in Europe. Ecography, 42(5), 956-967. https://doi. org/10.1111/ecog.04065
Lovas-Kiss, Á., Vincze, O., Kleyheeg, E., Sramkó, G., Laczkó, L., Fekete, R., ... Green, A. J. (2020). Seed mass, hardness and phylogeny determine the potential for endozoochory by granivorous waterbirds. Ecology and Evolution, 10, 1413-1424. https://doi.org/10.1002/ ece3.5997

Lovas-Kiss, Á., Vizi, B., Vincze, O., Molnár, V. A., \& Green, A. J. (2018). Endozoochory of aquatic ferns and angiosperms by mallards in Central Europe. Journal of Ecology, 106(4), 1714-1723. https://doi. org/10.1111/1365-2745.12913

Madriz, M. (1983). Food habits of the Brazilian duck in Apure State, Venezuela. The Journal of Wildlife Management, 47(2), 531-533. https://doi.org/10.2307/3808530

Maltchik, L., Rolon, A. S., Stenert, C., Machado, I. F., \& Rocha, O. (2011). Can rice field channels contribute to biodiversity conservation in Southern Brazilian wetlands? Revista De Biología Tropical, 59, 1895-1914.

Maurício, G. N., Bencke, G. A., Repenning, M., Machado, D. B., Dias, R. A., \& Bugoni, L. (2013). Review of the breeding status of birds in Rio Grande do Sul, Brazil. Iheringia. Série Zoologia, 103(2), 163-184. https://doi.org/10.1590/S0073-47212013000200012

Menegheti, J. O., \& Dotto, J. C. (2004). Avaliacao dos Estoques de Marreca-piadeira (Dendrocygna viudata), Marreca-caneleira (D. bicolor), y Marrecao (Netta peposaca) a través de contagens aereas. In M. M. Duarte (Ed.), Relatorio Final do Programa de Pesquisa e Monitoreamento de Fauna Cinengética do Rio Grande do Sul. Periodo 2004-2005. Porto Alegre, Brasil: Fundação Zoobotanica - Museu de Ciencias Naturais.

Nascimento, J. L. X., Koch, M., Efe, M. A., \& Scherer, S. B. (2005). Censos, anilhamentos e recuperações de duas marrecas no Rio Grande do Sul. Ornithologia, 1(1), 65-74.

Ntiamoa-baidu, Y., Piersma, T., Wiersma, P., Poot, M., Battley, P., \& Gordon, C. (1998). Water depth selection, daily feeding routines and diets of waterbirds in coastal lagoons in Ghana. Ibis, 140, 89-103. https://doi.org/10.1111/j.1474-919X.1998.tb04545.x

Pöysä, H., \& Poysa, H. (1983). Resource utilization pattern and guild structure in a waterfowl community. Oikos, 40, 295-307. https://doi. org/10.2307/3544594

R Development Core Team, R. F. F. S. C. (2019). . R: A language and environment for statistical computing.R Foundation for Statistical Computing, Vienna,Austria

Reynolds, C., \& Cumming, G. S. (2016a). Seed traits and bird species influence the dispersal parameters of wetland plants. Freshwater Biology, 61, 1157-1170. https://doi.org/10.1111/fwb.12776

Reynolds, C., \& Cumming, G. S. (2016b). Defining functional groups using dietary data: Quantitative comparison suggests functional classification for seed-dispersing waterfowl. Basic and Applied Ecology, 17(4), 333-343. https://doi.org/10.1016/j.baae.2015.12.006

Reynolds, C., Miranda, N. A. F., \& Cumming, G. S. (2015). The role of waterbirds in the dispersal of aquatic alien and invasive species. Diversity and Distributions, 21, 744-754. https://doi.org/10.1111/ ddi.12334

Rio Grande do Sul. (2019). Atlas Socioeconômico do Rio Grande do Sul (4th ed.). Porto Alegre, RS: Secretaria do Planejamento, Orçamento e Gestão.

Russo, N. J., Robertson, M., MacKenzie, R., Goffinet, B., \& Jimenez, J. E. (2020). Evidence of targeted consumption of mosses by birds in sub-Antarctic South America. Austral Ecology, 45(3), 399-403. https://doi.org/10.1111/aec.12858

Sick, H. (1997). Ornitologia brasileira. Rio de Janeiro, RJ: Nova Fronteira.

Silva, G. G., Green, A. J., Weber, V., Hoffmann, P., Lovas-Kiss, Á., Stenert, C., \& Maltchik, L. (2018). Whole angiosperms Wolffia columbiana disperse by gut passage through wildfowl in South America. Biology Letters, 14(12), 20180703. https://doi.org/10.1098/rsbl.2018.0703

Soons, M. B., Brochet, A. L., Kleyheeg, E., \& Green, A. J. (2016). Seed dispersal by dabbling ducks: An overlooked dispersal pathway for a 
broad spectrum of plant species. Journal of Ecology, 104(2), 443-455. https://doi.org/10.1111/1365-2745.12531

Summers, R. W., \& Grieve, A. (1982). Diet, feeding behaviour and food intake of the upland goose (Chloephaga picta) and ruddy-headed goose (C. rubidiceps) in the Falkland Islands. Journal of Applied Ecology, 783804. https://doi.org/10.2307/2403282

Tesson, S. V. M., Okamura, B., Dudaniec, R. Y., Vyverman, W., Löndahl, J., Rushing, C., ... Green, A. J. (2015). Integrating microorganism and macroorganism dispersal: Modes, techniques and challenges with particular focus on co-dispersal. Ecoscience, 22, 109-124. https://doi. org/10.1080/11956860.2016.1148458

Trevisan, R. (2005). O gênero Eleocharis R. Br. (Cyperaceae) no Rio Grande do Sul, Brasil. PhD Thesis, Universidade Federal do Rio Grande do Sul, UFRGS.

Troia, A. (2016). Dispersal and colonization in heterosporous lycophytes: Palynological and biogeographical notes on the genus Isoetes in the Mediterranean region. Webbia, 71(2), 277-281. https://doi. org/10.1080/00837792.2016.1191171

van Leeuwen, C. H., Van der Velde, G., van Groenendael, J. M., \& Klaassen, M. (2012). Gut travellers: Internal dispersal of aquatic organisms by waterfowl. Journal of Biogeography, 39(11), 2031-2040. https://doi.org/10.1111/jbi.12004

Viana, D. S., Santamaria, L., \& Figuerola, J. (2016). Migratory Birds as Global Dispersal Vectors. Trends in Ecology \& Evolution, 31, 763-775. https://doi.org/10.1016/j.tree.2016.07.005

Weber, P. A. P. (2014). Revisão taxonômica de Rhynchospora Vahl Seção Glaucae CB Clarke (Cyperaceae) para a América do Sul. MSc Dissertation. Universidade Federal de Santa Catarina, UFSC.

Welham, C. V. J. (1994). Flight speeds of migrating birds: A test of maximum range speed predictions from three aerodynamic equations. Behavioural Ecology, 5, 1-8. https://doi.org/10.1093/behec o/5.1.1
Wenny, D. G., Sekercioglu, C., Cordeiro, N. J., Rogers, H. S., \& Kelly, D. (2016). Seed dispersal by fruit-eating birds. Chapter five. In Ç. H. Sekercioglu, D. G. Wenny, \& C. J. Whelan (Eds.), Why birds matter: Avian ecological function and ecosystem services (pp. 107-145). Chicago, IL: University of Chicago Press.

Wetlands International (2020). Waterbird population estimates. Retrieved from wpe.wetlands.org on 26 June 2020.

Wilkinson, D. M., Lovas-Kiss, A., Callaghan, D. A., \& Green, A. J. (2017). Endozoochory of large bryophyte fragments by waterbirds. Cryptogamie, Bryologie, 38(2), 223-229. https://doi.org/10.7872/ cryb/v38.iss2.2017.223

Willson, M. F., Traveset, A., \& Sabag, C. (1997). Geese as frugivores and probable seed-dispersal mutualists (Gansos como frugívoros y probables mutualistas dispersadores de semillas). Journal of Field Ornithology, 68, 144-146.

\section{SUPPORTING INFORMATION}

Additional supporting information may be found online in the Supporting Information section.

How to cite this article: Silva GG, Green AJ, Hoffman P, et al. Seed dispersal by neotropical waterfowl depends on bird species and seasonality. Freshwater Biology. 2020;00:1-11. https://doi.org/10.1111/fwb.13615 